RESEARCH ARTICLE

\title{
Spatio-temporal variability in ontogenetic guild structure of an intertidal fish assemblage in central Chile
}

\author{
Variabilidad espacio-temporal en la estructura de gremios ontogenéticos \\ de un ensamble de peces intermareales de Chile central
}

\author{
PATRICIA A. BERRÍOS, ARIEL A. FARÍAS \& F. PATRICIO OJEDA*
}

Center for Advanced Studies in Ecology and Biodiversity, Department of Ecology,

Pontificia Universidad Católica de Chile, CP 6513677, Santiago, Chile

* Corresponding author: pojeda@bio.puc.cl

\begin{abstract}
Species resource use can vary throughout ontogeny, potentially affecting community dynamics. This can be particularly important for species facing high variability in environmental conditions and going through several orders of magnitude in size, as intertidal fishes. However, the influence of the resulting ontogenetic changes in guild membership on the spatio-temporal structure of fish assemblages remains virtually unknown. Here we assessed the spatial and temporal variability in the ontogenetic feeding guild (OFG) structure of the fish assemblage inhabiting the temperate rocky intertidal zone along central Chilean coast. This was done applying principal component analysis (PCA) and randomization tests (R-test) on the relative OFG composition of fish assemblages, obtained from seasonal samples from ten pools located at two heights in the intertidal zone in three localities between $33^{\circ}$ and $34^{\circ} \mathrm{S}$. Overall, the PCA and R-tests suggest that spatial variability dominated over temporal variability in OFG structure, mainly due to a higher representation of omnivore species at high intertidal pools in two of the three sampled localities. However, phenology-related changes in the representation of fish size-classes (i.e. carnivore recruitment in spring-summer) along with ontogenetic differences in habitat selection (e.g., selection for low intertidal pools by bigger-sized carnivore OFG) contributed to both spatial and temporal differentiation in OFG structure. Finally, the relative representation of each OFG correlated with that of their dominant species, without evidence for density compensation. This suggests low levels of functional redundancy among species in each OFG, highlighting the vulnerability of assemblage functioning to size-biased disturbances as fishing.
\end{abstract}

Key words: intertidal fishes, ontogenetic feeding guilds, spatio-temporal variability.

\section{RESUMEN}

El uso de los recursos puede variar a través de la ontogenia, afectando potencialmente las dinámicas comunitarias. Esto puede ser de particular importancia en especies que enfrentan alta variabilidad en las condiciones ambientales, especialmente en peces intermareales, los que alcanzan varios órdenes de magnitud en tamaño corporal. Sin embargo, la influencia de los cambios ontogenéticos en la membresía gremial sobre la estructura espacio-temporal de los ensambles de peces permanece virtualmente desconocida. En este trabajo estudiamos la variabilidad espacio-temporal en la estructura de los gremios alimenticios ontogenéticos (OFG) de los ensambles de peces intermareales que ocurren en el intermareal rocoso de la costa de Chile central. Para esto realizamos análisis de componentes principales (PCA) y pruebas de aleatorización (pruebas R) de la composición relativa de las OFG de estos ensambles, obtenidos de muestreos estacionales en diez pozas intermareales ubicadas en dos alturas de mareas en la zona intermareal en tres localidades entre $\operatorname{los} 33^{\circ}$ y $34^{\circ} \mathrm{S}$. En general, los PCA y pruebas R sugieren que la variabilidad espacial domina sobre la variabilidad temporal en la estructura de las OFG, debido principalmente a la alta representatividad de las especies omnívoras en las pozas altas del intermareal en dos de las tres localidades muestreadas. Sin embargo, cambios relacionados a la fenología en la representación de las clases de tamaño de los peces (i.e. reclutamiento de carnívoros en primavera-verano) junto con diferencias ontogenéticas en la selección de hábitat (e.g., selección por pozas del intermareal bajo por la OFG de carnívoros de gran tamaño) contribuyeron a una diferenciación espacial y temporal de la estructura de la OFG. Finalmente, la representación relativa de cada OFG se correlacionó con la de sus especies dominantes, sin evidencia de una compensación por densidad. Esto sugiere bajos niveles de redundancia funcional entre las especies en cada OFG, lo cual denota la vulnerabilidad del funcionamiento de estos ensambles a perturbaciones sesgadas en tamaño corporal tales como la pesca.

Palabras clave: gremios alimenticios ontogenéticos, peces intermareales, variabilidad espacio-temporal. 


\section{INTRODUCTION}

The study of temperate intertidal fish assemblages has received considerable attention in the last three decades, with several lines of research aiming to identify factors underlying the regulation of their structure and organization (e.g., Gibson 1982, Grossman 1982, Werner \& Gilliam 1984, Horn \& Gibson 1988, Horn 1989, Stepien 1990, Varas \& Ojeda 1990, Muñoz \& Ojeda 1997, 1998, Angel \& Ojeda 2001, Wennhage \& Pihl 2002, Boyle \& Horn 2006). A common issue in this kind of studies is dealing with the inherent complexity of species assemblages, partly due to intra (e.g., phenological, ontogenetic, behavioral) and interspecific variability in the responses shown by their constituent species (Simberloff \& Dayan 1991, Jaksic et al. 1993, Muñoz \& Ojeda 1998, Rosenfeld 2002, Gillanders et al. 2003, Farías \& Jaksic 2009). One way of approaching this task is by focusing attention on natural units other than species populations, such as guilds and functional groups, in order to reduce the complexity of the study system (Jaksic 1981, Simberloff \& Dayan 1991, Wilson 1999, Blondel 2003). This approach assumes that the behavior of the resulting aggregations synthesizes the responses of individuals that, because their ecological similarities, are expected to react similarly to environmental forcing (e.g., fluctuations in resource availability or abiotic factors), irrespective of their taxonomic affiliation.

Guilds, in particular, were defined by Root (1967) as "a group of species that exploit the same class of environmental resources in a similar way", or in other words, species that strongly overlap in resource use. Moreover, whenever an ecosystem function is closely related to resource consumption, assessing the guild structure of a given assemblage allows identifying groups of species playing similar roles regarding such function (i.e., functional groups; Petchey \& Gaston 2002, Blondel 2003, Petchey \& Gaston 2006, Farías \& Jaksic 2009, 2011). For example, through food consumption, consumer species mediate the processes of energy and nutrient transfer through the food web and, thus, they can be assigned to functional groups according their similarity in dietary habits (i.e. their trophic guild affiliation; Wilson 1999, Blondel 2003). Accordingly, species of the same trophic guild impact on a similar set of resources and affects the same paths of energy/nutrient flow in the ecosystem. Such functional redundancy putatively increases ecosystem resilience to environmental disturbances affecting the abundance of some species (Walker 1992, 1995, Naeem 1998, Wilson 1999, Fonseca \& Ganade 2001, Jaksic 2003). Strictly, functional redundancy only exists if density compensation occurs among species in a functional group across any environmental gradient (Rosenfeld 2002, Loreau 2004, Petchey \& Gaston 2006). Thus, assessing spatio-temporal trends in guild structure not only gives information on factors determining community structure but also has connotations for functional interpretation of the dynamics of consumer assemblages.

Studies on vertebrate assemblages have revealed that guild structure may vary as species composition changes in response to environmental heterogeneity in space and time (e.g., Nudds 1983, Feinsinger et al. 1985, Angel \& Ojeda 2001, Farías \& Jaksic 2007a, 2007b). Another important factor influencing guild structure are changes in resource use experienced by individuals throughout their lifespan, which eventually makes a given species part of different guilds in distinct stages in life (Polis 1984, Werner \& Gilliam 1984, Muñoz \& Ojeda 1998). In this sense, species that go through a wide range of sizes during ontogeny tend to experience changes in their foraging abilities and metabolism, which in turn determine changes in energy demands and resource use (Gibson 1982, Jackson et al. 2004). Accordingly, some degree of variability in guild structure may arise from factors as species phenology, habitat shift (e.g., due to migration; Gillanders et al. 2003), and fluctuations in prey availability or predation risk (Polis 1984, Werner \& Gilliam 1984, Werner \& Hall 1988, Jackson et al. 2004, Rojas \& Ojeda 2010, Pulgar et al. 2011). Thus, applying guild structure analyses on age or size classes instead of whole species (i.e., assessing the ontogenetic feeding guilds, OFG; Muñoz \& Ojeda 1998) may render a more reliable picture of the dynamics of species assemblages.

Variations in body size are especially important in fishes, ranging several magnitude orders before reaching adulthood (Werner \& 
Hall 1988). However, despite guild structure has been widely used for synthesizing fish community patterns and assessing their dynamics in different aquatic ecosystems (e.g., Varas \& Ojeda 1990, Angel \& Ojeda 2001, Wennhage \& Pihl 2002, and many others), just a minor proportion of such studies took into account ontogenetic variations in their trophic ecology (e.g., Muñoz \& Ojeda 1998, Davis 2000, Admunsen et al. 2003, Hajisamae et al. 2004, Castellanos-Galindo \& Giraldo 2008, Reum \& Essington 2008, Specziar \& Rezsu 2009, Kellnreitner et al. 2011). The emerging view from these studies is that ontogeny is as important as taxonomy in determining the guild membership of fish species, though little is still known about its effects on spatial and temporal differentiation in guild structure (but see Davis 2000, Castellano-Galindo \& Giraldo 2008, Reum \& Essington 2008, Kellnreitner et al. 2011). Rocky intertidal habitats, in particular, are known to be highly variable in time and space, mainly due to two dominant physical gradients, namely, wave exposition and tidal flow, the latter also affecting temperature and nutrient concentration in tidepools (Menge \& Branch 2001). Further, most carnivore fish species that inhabit these habitats in temperate Chile have been shown to experience significant ontogenetic changes in diet, shifhting among trophic guilds throughout their lives (Muñoz \& Ojeda 1998). The relevance of such ontogenetic patterns for spatial and temporal differentiation of tidepool fish assemblages is still unknown.

In this context, the objective of the present study is to assess the variability in the structure of the fish assemblage inhabiting the temperate rocky intertidal zone of central Chile, regarding the abundance of species' ontogenetic (i.e. size) classes in each OFG. Because the feeding habits of these species are fairly conserved within each size class (Muñoz \& Ojeda 1998), the OFG structure of the fish assemblage can be inferred from the size distribution of the involved species in samples at different places and times, and tested for differences among the latter to assess spatial and temporal variability. Temporal variability was assessed at a seasonal resolution, accounting for the effects of fish phenology. Further, spatial variability was assessed at two distinct levels of resolution: "among-localities" through the entire region, and "between-heights" of the intertidal zone in each locality. Accordingly, the effects of local contingency (e.g., local size-dependent fishing pressure and rocky-intertidal structure) and microhabitat use, respectively, were analyzed. Finally, by closely inspecting the observed changes in abundance distributions within each OFG, the existence of redundancy among trophically similar species is also discussed.

\section{METHODS}

\section{Study sites and fish samplings}

Ten intertidal tidepools were selected in three localities along the central Chilean coast between $33^{\circ}$ and $34^{\circ}$ South latitude, four pools in Isla Negra $\left(33.4^{\circ} \mathrm{S}\right)$, three at El Tabo $\left(33.45^{\circ} \mathrm{S}\right)$, and three at Las Cruces $\left(33.5^{\circ}\right.$ S) (see Fig. 1). The pools were sampled every month from January to December 2004, so as to estimate abundance and size distribution of the existing intertidal fish assemblages. Sampling consisted of suctioning out the water contained in the pools during the tidal ebb by means of a portable water pump (Tecumseh $5 \mathrm{Hp}$ ). The nozzle of the hose was placed perpendicular to and at the bottom of the pool, in order to prevent fishes from being sucked into the pump. Once the water was extracted fish anesthetic BZ 20 (benzocaine) was applied under boulders and inside crevices thereby facilitating the capture of the specimens. Fish were then collected with hand nets and placed in cooler tanks with fresh seawater and constant air supply. Individuals were identified to species and measured to the nearest $\mathrm{mm}$. After pools had been replenished with seawater using

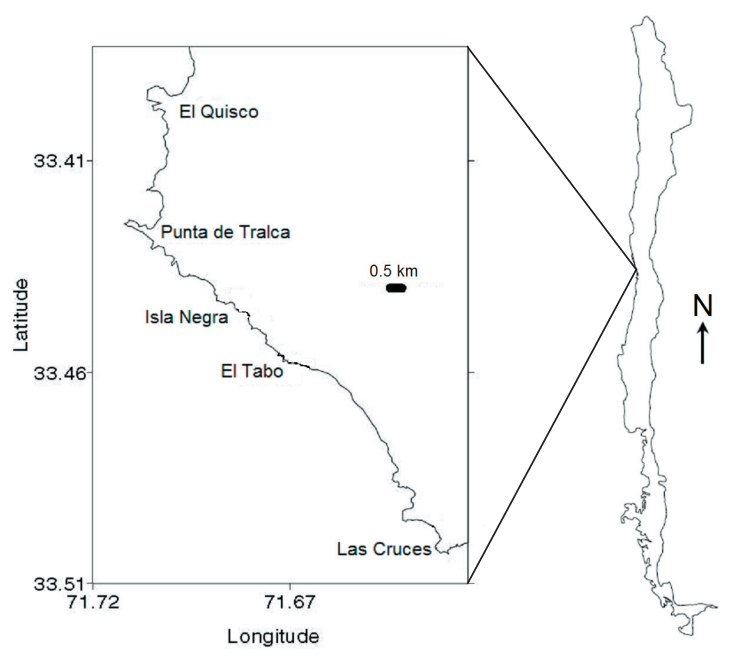

Fig. 1: Study area showing the three localities where rock pools were sampled.

Área de estudio de las tres localidades en donde se muestrearon las pozas intermareales. 
the water pump, fish were then returned to their original pool. These pools were classified according to their distance to mean low water level (MLWL), and were thus labeled as high and low tide pools (see Hernández et al. 2002). Some species typical from the subtidal zone were detected only sporadically at intertidal pools. Because they inhabit and develop most of their life cycle out of the intertidal zone (Angel \& Ojeda 2001), their occurrence is just accidental or transitory (e.g., dispersing individuals). Thus, these species are not expected to contribute significantly to assemblage functional structure or to be functionally redundant with intertidal species, and they were not considered in the subsequent analyses. Residence time of these species inhabiting rocky intertidal pools of central Chile has been well documented by Varas \& Ojeda (1990), Muñoz \& Ojeda (1998) and Pulgar et al. (2005).

\section{Ontogenetic feeding guilds (OFG's)}

It has been previously noted that, for fish species in the assemblage under study, diet composition is fairly conservative within size classes across time and space (see Varas \& Ojeda 1990, Stepien 1990, Muñoz \& Ojeda 1997, 1998, 2000), and OFG membership of an individual can be deduced from its size and taxonomic identity. Accordingly, OFG classification was carried out based on the categories already established by Muñoz and Ojeda (1998) for carnivore intertidal fishes along the central Chilean coast (using the same nomenclature), and by Muñoz and Ojeda (1997, 2000) for herbivore and omnivore intertidal fish along the central Chilean coast. Under such considerations, the fish assemblage inhabiting the rocky intertidal zone of the central Chilean coast was divided into the following seven ontogenetic food guilds: OFG A, composed of carnivore fish size classes, whose main food supply are harpacticoid copepods, OFG B, which constitutes fish that mainly consume gamarid amphipods, OFG $\mathrm{C}$, whose members consume amphipods and decapod crustaceans, OFG D, whose members mainly consume fish and, secondly, decapod crustaceans, OFG $\mathrm{O}$, which includes omnivores that consume a wide variety of mobile and sessile invertebrates, as well as foliose and filamentous macroalgae, and finally, OFG V and OFG R which refer to herbivore fish whose principal food item are green macroalgae Ulva spp. and Enteromorpha spp. (Chlorophyta) and the red seaweed Gelidium chilense (Rhodophyta), respectively.

\section{Data analysis}

Qualitative characterization of variability in guild structure

Data obtained for each locality-height-season combination were treated as different samples for subsequent analyses. Then, for each sample, individuals of species/size-classes belonging to the same trophic guild were pooled together, and the resulting matrix of guild relative abundance in each sample was entered as input data in a Principal Component Analysis (Gotelli \& Ellison 2004). This was done in order to qualitatively assess the guilds that explained most variability in the guild structure of the assemblage (i.e. those presenting the highest loadings in the resulting first two principal components).

Quantitative testing of variability in guild structure
The observed qualitative patterns of variability in guild structure were statistically tested among samples by means of Randomization Tests (Gotelli \& Graves 1996, Manly 1998). Three randomization trials were designed to isolate the effects of the three variation sources of interest (i.e. locality, height and season). In order to quantify differences in the relative abundance of guilds among samples, Bray-Curtis percent similarity indices $\left(\mathrm{BC}_{\mathrm{ob}}\right)$ were calculated in each trial among all levels of the variation source of interest (3 levels for locality, 2 levels for height and 4 levels for season, which rendered 3,1 and $6 \mathrm{BC}_{\mathrm{ob}}$ values, respectively), within each combination of the remaining two sources of variation. Afterwards, the observed number of individuals for each species/size-class was reassigned 5000 times among samples within such combinations, maintaining the total number of individuals in each sample constant. These constraints (constant number of individuals for each species/size-class and sample) on the randomization procedure was applied in order to preserve differences in relative abundance and size-class profiles as well as sample size resulting from local/seasonal environmental conditions (e.g., pool size, productivity, etc.), by using the Patefield (1981) algorithm implemented by the r2dtable function in the $\mathrm{R}$ software (R Development Core Team 2006). Bray-Curtis indices were recalculated in each iteration, obtaining the distribution and mean $\left(\mathrm{BC}_{\mathrm{ex}}\right)$ of the respective 5000 randomized values $\left(\mathrm{BC}_{\mathrm{rd}}\right)$ for each comparison, against which to compare the $\mathrm{BC}_{\mathrm{ob}}$ values. The probability of each $\mathrm{BC}_{\mathrm{ob}}\left(\mathrm{P}_{[\leq \mathrm{BCob}]}\right)$ was then obtained as the number of $\mathrm{BC}_{\mathrm{rd}} \leq \mathrm{BC}_{\mathrm{ob}}$ divided by the number of randomizations performed (Gotelli \& Graves 1996, Manly 1998). Thus, significant differences between two samples (i.e. significantly low Bray-Curtis index values) were assumed whenever $\mathrm{P}_{[\leq \mathrm{BCob}]}<\alpha_{\text {adj }}$, where $\alpha_{\text {adj }}$ corresponds to the Bonferroni-adjusted significance level (i.e. $\alpha_{\text {adj }}=\alpha=0.05, \alpha_{\text {adj }}=\alpha / 3=0.0167$ and $\alpha_{\text {adj }}$ $=\alpha / 6=0.0083$ for height, locality and season trials, respectively, Gotelli \& Ellison 2004).

Assessing density compensation and functional redundancy

For the fish assemblage under study, functional redundancy implies density compensation between species/size classes with similar trophic habits, buffering overall temporal or spatial fluctuations in the abundance of OFG's. Accordingly, the abundance of two or more species should covariate negatively, and the total abundance of functional groups should not correlate with their composition. However, paired correlations between species/size-classes abundances are not appropriate to assess density compensation in specious guilds because fluctuation in the abundance of one or few dominant species (i.e., those with higher abundance than expected from an even representation of species/size classes in the OFG) could be compensated by small changes on many others, with little or no significant bivariate correlations. Thus, we analyzed species' covariation at the OFG level applying principal component analysis (PCA) on a matrix of abundance (i.e. recorded number of individuals) of species/size classes for each combination of factors (i.e. locality height ' season). This allowed: (1) to assess the subsets of species/size classes accounting for most variability in OFG composition as those showing the highest loadings in the first axes of the PCA (i.e., axes explaining $\geq 5$ $\%$ of variability in composition), and (2) to identify the main species/size classes showing covariation in their abundance. In the latter case, density compensation 
between subsets of species/size classes is indicated by opposite loadings in first axes of the corresponding PCA. Finally, the total abundance of each OFG was regressed against scores for such axes, and low values for the resulting determination coefficients $\left(\mathrm{R}^{2}\right)$ interpreted as indicative of functional redundancy.

\section{RESULTS}

\section{Ontogenetic feeding guilds}

A total of 4039 tide-pool fish was collected and classified, belonging to 12 species distributed in seven families (Table 1). Blennioids constituted the dominant group in the rocky-intertidal fish assemblage along central Chile based on both species number and abundance, represented by seven species of the Blenniidae, Tripterygiidae and Labrisomidae families, followed by two Kyphosidae, one Bovichtidae, one Gobiesocidae and one Gobiidae (Table 1). Other four species (i.e., Aphos porosus [Batrachoididae], Aplodactylus punctatus [Aplodactylidae], Cheilodactylus variegatus [Cheilodactylidae] and Labrisomus philippi [Labrisomidae]) typical from the subtidal zone (only 41 individuals

TABLE 1

Species list, number of individuals analyzed $(\mathrm{N})$, and sizes of the 12 species that make up the rocky intertidal fish assemblage of central Chile.

Lista de especies, número de individuos analizados $(\mathrm{N})$, y tamaños de las 12 especies que componen el ensamble de peces del intermareal rocoso de Chile central.

\begin{tabular}{|c|c|c|c|}
\hline \multirow[t]{2}{*}{ Species } & \multirow[t]{2}{*}{$\mathrm{N}$} & \multicolumn{2}{|c|}{ Total length $(\mathrm{mm})$} \\
\hline & & $\mathrm{X} \pm \mathrm{SE}$ & Range \\
\hline \multicolumn{4}{|l|}{ Blenniidae } \\
\hline Hypsoblennius sordidus (Bennett, 1828) & 101 & $49.9 \pm 18.4$ & $26-122$ \\
\hline Scartichthys viridis (Valenciennes, 1836) & 2407 & $118.3 \pm 28.5$ & $30-290$ \\
\hline \multicolumn{4}{|l|}{ Tripterygiidae } \\
\hline Helcogrammoides chilensis (Cancino, 1960) & 309 & $41.9 \pm 12.8$ & $15-86$ \\
\hline Helcogrammoides cunninghami (Smitt, 1898) & 107 & $40.8 \pm 7.8$ & $28-65$ \\
\hline \multicolumn{4}{|l|}{ Labrisomidae } \\
\hline Auchenionchus microcirrhis (Valenciennes, 1836) & 149 & $127.8 \pm 47.8$ & $28-275$ \\
\hline Auchenionchus variolosus (Valenciennes, 1836) & 11 & $84.5 \pm 34.8$ & $36-146$ \\
\hline Calliclinus geniguttatus (Valenciennes, 1836) & 4 & $143.3 \pm 31.2$ & $97-165$ \\
\hline \multicolumn{4}{|l|}{ Kyphosidae } \\
\hline Girella laevifrons (Tschudi, 1846) & 476 & $68.2 \pm 37.6$ & $18-175$ \\
\hline Graus nigra Philippi, 1887 & 278 & $129.1 \pm 32.2$ & $39-226$ \\
\hline \multicolumn{4}{|l|}{ Bovichtidae } \\
\hline Bovichtus chilensis Regan, 1913 & 140 & $73.9 \pm 18.8$ & $38-134$ \\
\hline \multicolumn{4}{|l|}{ Gobiesocidae } \\
\hline Gobiesox marmoratus Jenyns, 1842 & 47 & $67.4 \pm 26.6$ & $15-125$ \\
\hline \multicolumn{4}{|l|}{ Gobiidae } \\
\hline Ophiogobius jenynsi Hoese, 1976 & 10 & $50.7 \pm 12.0$ & $32-71$ \\
\hline Total & 4039 & & \\
\hline
\end{tabular}


captured between October and January) were not considered in the analyses.

The fish assemblage is composed of nine carnivore, two omnivore and one herbivore species, which become 21 carnivore, two omnivore and five herbivore species/size classes upon establishing the OFG's (Table 2). The blenniid Scartichthys viridis is the only true herbivore in the assemblage (ca. $90 \%$ of algae in diet), with three size classes assigned to OFG $\mathrm{V}$ and two to OFG R. Two omnivore species (i.e, the blenid Hypsoblennius sordidus and the kyphosid Girella laevifrons) constitute OFG O irrespective of body size, consuming both sessile and mobile invertebrates along with foliose and filamentous macroalgae, though $H$. sordidus feeds more on cirripeds and $G$. laevifrons does it on green algae. Further, the former and the latter numerically dominated the guild in the high and low intertidal, respectively (Fig. 2).

Out of the nine carnivore species, only Ophiogobius jenynsi and Helcogrammoides cunninghami show their two recorded size classes belonging to a single guild (OFG $A$ and OFG $B$, respectively, see Table 2), the later being numerically dominant (Fig. 2). Three species (i.e., Helcogrammoides chilensis, Gobiesox marmoratus and Calliclinus geniguttatus) joined two OFG's (i.e., OGF $\mathrm{A}$ and $\mathrm{B}, \mathrm{OFG} \mathrm{B}$ and $\mathrm{C}$, and $\mathrm{OFG} \mathrm{C}$ and $\mathrm{D}$, respectively), depending on size. Collected individuals of $H$. chilensis and $G$. marmoratus were representative of the size range found regionally in the rocky intertidal zone, but those of $C$. geniguttatus were always longer than $9.7 \mathrm{~mm}$ (in $\mathrm{T}_{\mathrm{L}}$ ). The remaining four carnivore species show strong ontogenetic change in their feeding habits, thus belonging to three or four different OFG's (Table 2) in distinct stages of their lives.

The abundance of members of each OFG varies greatly when considering the areas of the intertidal zone where they come from. Six of the seven established OFG's made the greatest contributions of abundance from the low pools (Fig. 3A). On the contrary, OFG O contributed greater total abundance from high pools at two localities (Fig. 3A), mainly due to the presence of the temporary resident species $G$. laevifrons.

Qualitative patterns of differentiation in guild structure
The first two principal components comprise almost all variability (96.5\%) in guild structure among fish assemblages (Table 3). The first component (PC1) explains most variability $(87.4 \%)$, representing the relative importance of herbivores feeding mainly on green algae (OFG V, negative scores), and omnivores (OFG O, positive scores, Table 3 ). In turn, the second component (PC2) accounted for a much smaller portion of the observed variability in guild structure $(9.1 \%)$, describing the relative importance of the former two guilds (i.e. $\mathrm{V}$ and $\mathrm{O}$, negative scores) in relation to that of carnivorous guilds (guilds A-D, positive scores, Table 3), particularly those specialized in the consumption of amphipods and decapods (i.e. guilds $\mathrm{B}$ and $\mathrm{C}$ ). Overall, spatial differentiation in guild structure, both among localities and between heights in the intertidal zone, occurs along the PC1. Fish assemblages in highintertidal pools at Las Cruces and Isla Negra are dominated by herbivores feeding mainly on green algae (high PC 1 scores; Fig. 3B). Conversely, temporal differentiation in guild structure occurred mainly along the PC2, with summer-spring samples presenting higher scores than autumn-winter ones (Fig. 3B, right panel). Thus, most of the observed variability in guild structure is attributable to a relatively higher representation of omnivores (and lower of herbivores) in the high-intertidal pools at Las Cruces and Isla Negra, a pattern not detected at El Tabo. Thereafter, some temporal differentiation occurred due to a higher representation of carnivores, particularly those consuming amphipods and decapods, during summer and spring (Fig. 3A).

\section{Quantitative testing of differentiation in guild structure}

Overall, the qualitative patterns described above were supported by randomization tests. On the one hand, El Tabo was the locality that showed the lowest differentiation (i.e. higher values for the Bray-Curtis percent similarity index, Table 4, see details in Appendix) in guild structure between high and low-intertidal pools throughout the whole year. Thus, while such differentiation was always highly significant for Las Cruces and Isla Negra, it was significant only during autumn and winter at El Tabo (Fig. 4). Furthermore, though differentiation in guild 
TABLE 2

Ontogenetic feeding guilds (OFG's) occupied by the 12 species of intertidal fish as a function of their total length. In addition, loadings of each species/size class in the main axes of variation in OFG-composition, defined from principal component analyses of their abundances, are displayed. Only axes explaining $\geq 5 \%$ of the observed variability (in brackets) and loadings $\geq 0.100$ are shown.

Gremios alimenticios ontogenéticos (OFG's) ocupados por las 12 especies de peces intermareal en relación a su longitud total. Además, se muestra el peso de cada clase de especie/tamaño en los ejes principales de variación en composición de los OFG's, definidos a partir de análisis de componentes principales de sus abundancias. Solo se presentan los ejes que explican $\geq 5 \%$ de la variabilidad observada y pesos $\geq 0.100$.

\begin{tabular}{|c|c|c|c|c|c|}
\hline \multirow{2}{*}{ Main Guild } & \multirow{2}{*}{ OFG } & \multirow{2}{*}{ Species/size class } & \multicolumn{3}{|c|}{ PCA loadings } \\
\hline & & & PC 1 & PC 2 & PC 3 \\
\hline \multirow[t]{25}{*}{ Carnivores } & $\mathrm{A}$ & A. variolosus $(36-60 \mathrm{~mm})$ & & & \\
\hline & & H. chilensis $(15-40 \mathrm{~mm})$ & -1.000 & & \\
\hline & & O. jenynsi $(32-71 \mathrm{~mm})$ & & & \\
\hline & & [\% Explained Variance] & [99.6\%] & & \\
\hline & B & A. microcirrhis $(28-60 \mathrm{~mm})$ & -0.100 & -0.107 & \\
\hline & & A. variolosus $(61-80 \mathrm{~mm})$ & & & \\
\hline & & B. chilensis $(38-70 \mathrm{~mm})$ & -0.297 & -0.844 & 0.428 \\
\hline & & G. nigra $(39-80 \mathrm{~mm})$ & & 0.156 & 0.165 \\
\hline & & G. marmoratus (15-50 mm) & & & \\
\hline & & H. chilensis (41-86 mm) & -0.619 & 0.494 & 0.570 \\
\hline & & H. cunninghami (28-65 mm) & -0.718 & & -0.680 \\
\hline & & [\% Explained Variance] & [79.9\%] & {$[12.7 \%]$} & [5.5\%] \\
\hline & $\mathrm{C}$ & A. microcirrhis $(61-110 \mathrm{~mm})$ & & & \\
\hline & & A. variolosus $(81-110 \mathrm{~mm})$ & & & \\
\hline & & B. chilensis $(71-100 \mathrm{~mm})$ & -0.239 & & \\
\hline & & C. geniguttatus $(97-120 \mathrm{~mm})$ & & & \\
\hline & & G. marmoratus $(51-125 \mathrm{~mm})$ & & & \\
\hline & & G. nigra $(81-190 \mathrm{~mm})$ & -0.967 & & \\
\hline & & [\% Explained Variance] & [94.8\%] & & \\
\hline & $\mathrm{D}$ & A. microcirrhis (111-275 mm) & 0.997 & & \\
\hline & & A. variolosus (111-146 mm) & & & \\
\hline & & B. chilensis $(101-134 \mathrm{~mm})$ & & -0.987 & \\
\hline & & C. geniguttatus (121-165 mm) & & -0.124 & \\
\hline & & G. nigra $(191-226 \mathrm{~mm})$ & & -0.101 & \\
\hline & & [\% Explained Variance] & [90.6\%] & {$[8.2 \%]$} & \\
\hline \multirow[t]{3}{*}{ Omnivores } & $\mathrm{O}$ & G. laevifrons $(18-175 \mathrm{~mm})$ & -0.999 & & \\
\hline & & H. sordidus $(26-122 \mathrm{~mm})$ & & -0.999 & \\
\hline & & [\% Explained Variance] & [93.8\%] & {$[5.2 \%]$} & \\
\hline \multirow[t]{2}{*}{ Herbivores } & $\mathrm{V}$ & S. viridis $(30-175 \mathrm{~mm})$ & & & \\
\hline & $\mathrm{R}$ & S. viridis $(176-290 \mathrm{~mm})$ & & & \\
\hline
\end{tabular}



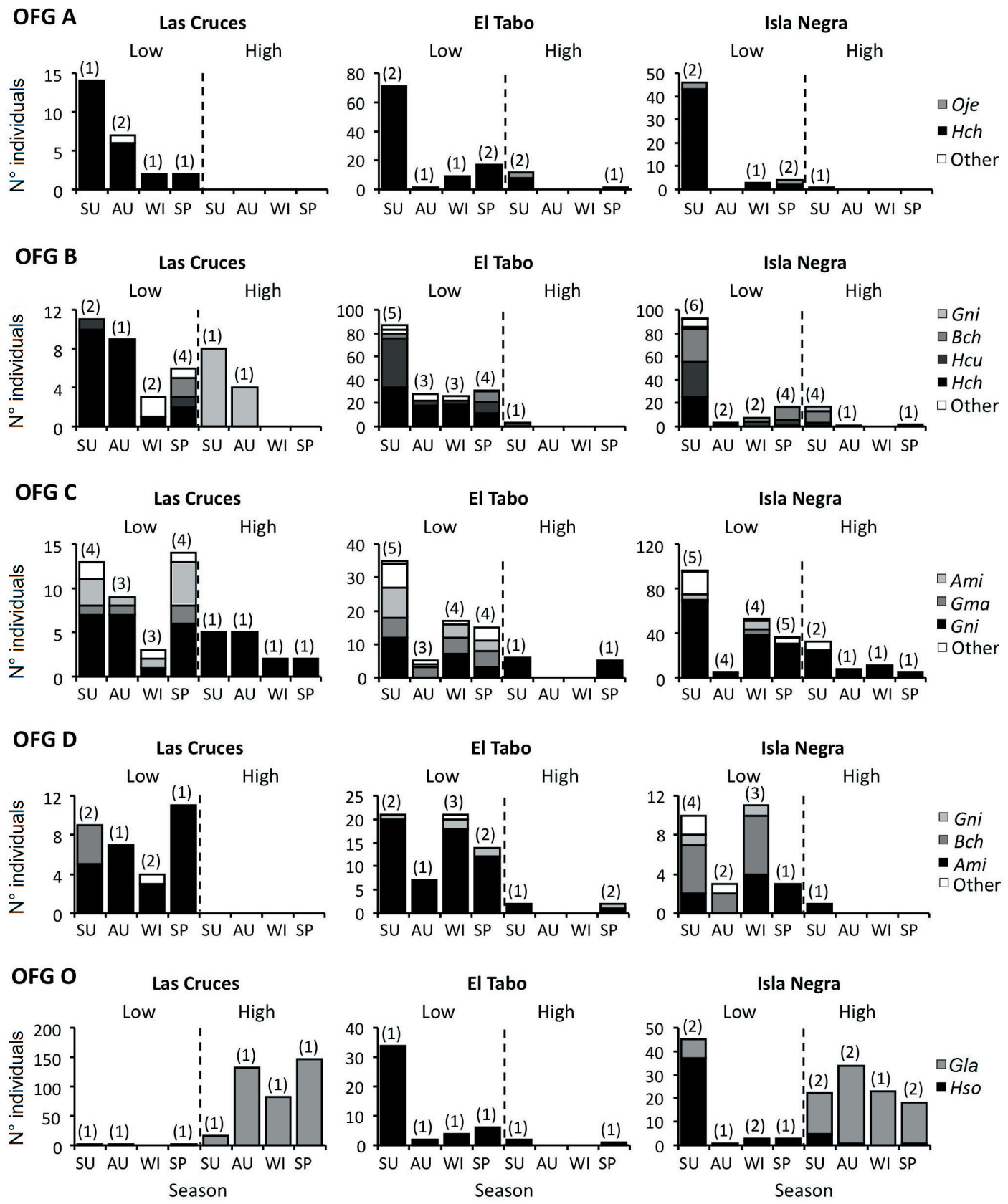

Fig. 2: Spatio-temporal variability in the composition of ontogenetic feeding guilds (OFG, nomenclature as detailed in the main text) with more than one species. The abundance ( $\mathrm{n}^{\circ}$ of individuals in all sampled pools) for the more abundant species in each OFG is shown in bars, by locality, height in the intertidal zone and season (SU: summer, AU: autumn, WI: winter, SP: spring); in each case the total number of species is shown between parentheses. Note that the scale of the axes varies among plots. Ami: Auchenionchus microcirrhis, Bch: Bovichtus chilensis, Gla: Girella laevifrons, Gma: Gobiesox marmoratus, Gni: Graus nigra, Hch: Helcogrammoides chilensis, Hcu: Helcogrammoides cunninghami, Hso: Hypsoblennius sordidus, Oje: Ophiogobius jenynsi.

Variabilidad espacio-temporal en la composición de los gremios alimenticios ontogenéticos (OFG, nomenclatura similar a la descrita en el texto) con más de una especie. Las barras muestran la abundancia ( $\mathrm{n}^{\circ}$ de individuos en todas las pozas muestreadas) para las especies más abundantes en cada OFG por localidad, altura en el intermareal y estación del año (SU: verano, AU: otoño, WI: invierno, SP: primavera); en cada caso el número total de especies es presentado entre paréntesis. Notar que la escala de los ejes varía entre gráficos. Ami: Auchenionchus microcirrhis, Bch: Bovichtus chilensis, Gla: Girella laevifrons, Gma: Gobiesox marmoratus, Gni: Graus nigra, Hch: Helcogrammoides chilensis, Hcu: Helcogrammoides cunninghami, Hso: Hypsoblennius sordidus, Oje: Ophiogobius jenynsi. 
structure among localities was always highly significant for high-intertidal pools (where samples from Las Cruces and Isla Negra were more distinctive and showed higher variability in guild structure, Fig. 2B, left panel), such differentiation became less clear for lowintertidal pools (Fig. 4). Hence, randomization tests confirmed the importance of the level of distinctiveness reached by fish assemblages in high-intertidal pools at Las Cruces and Isla Negra as the main driver of the spatial differentiation observed in guild structure.

In time, autumn and winter samples never showed significant differences in guild structure (as evidenced by the high values of the corresponding Bray-Curtis similarity indices), and most of the differentiation arose among these and the remaining seasons (Fig.

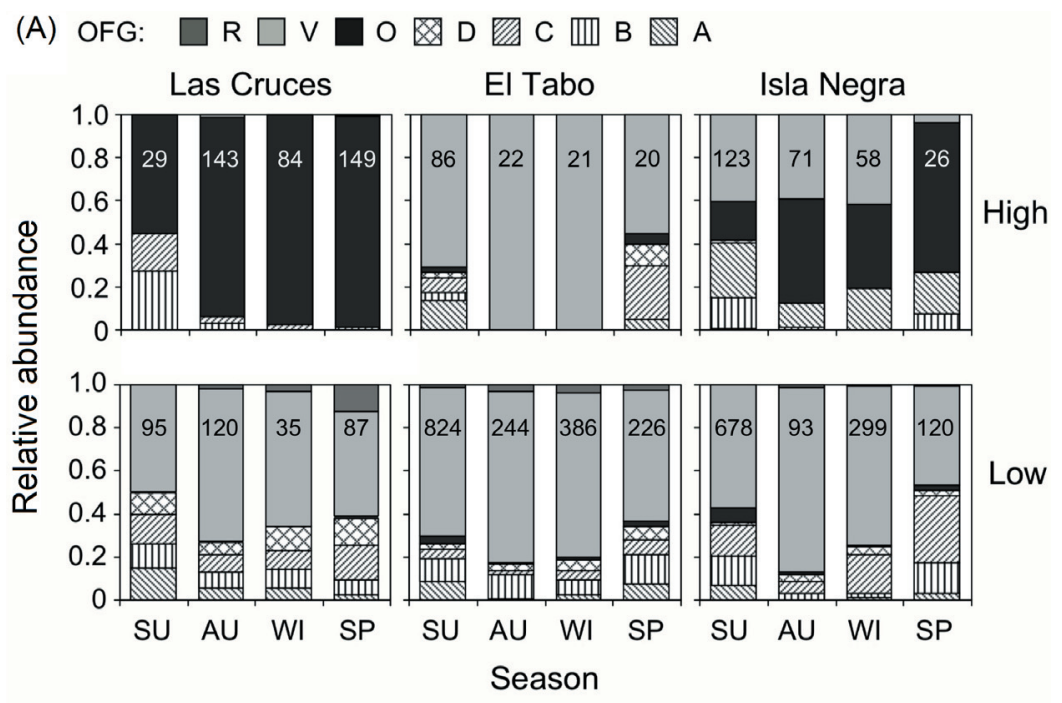

(B)

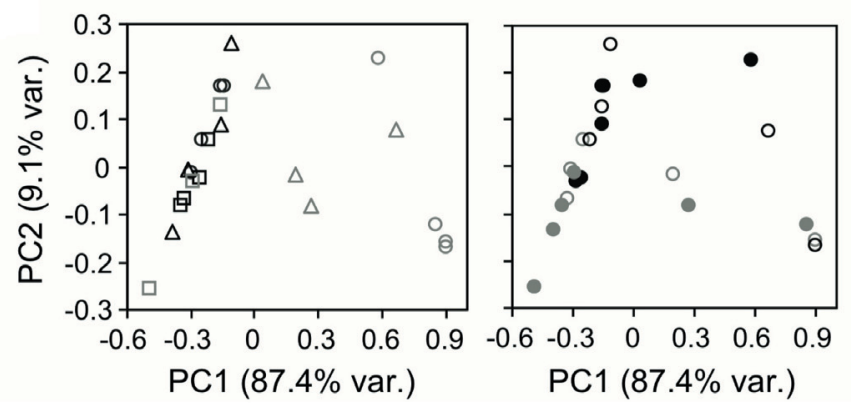

Fig. 3: Spatio-temporal dynamic of the ontogenetic feeding guild (OFG) structure of the intertidal fish assemblage in Central Chile. (A) Spatio-temporal variation in the relative representation obtained as fraction of total abundance (i.e., numbers within bars: $\mathrm{n}^{\circ}$ individuals in the sampled intertidal pools) of each OFG by locality, height in the intertidal zone and season (SU: summer, AU: autumn, WI: winter, SP: spring). (B) Results of principal component analysis (first two principal components, see Table 3) applied on relative representation of OFG's highlighting spatial (left panel, grey and black dots represent high and low intertidal, respectively, circles: Las Cruces, squares: El Tabo, triangles: Isla Negra) and temporal (right panel, filled black: summer, open black: spring, filled grey: autumn, open grey: winter) variability in ontogenetic feeding guild structure.

Dinámica espacio-temporal de la estructura de los gremios alimenticios ontogenéticos (OFG) de los ensambles de peces intermareales de Chile central. (A) Variación espacio-temporal en la representación relativa obtenida como fracción de la abundancia total (i.e., números dentro de barras: $\mathrm{n}^{\circ}$ de individuos en las pozas muestreadas) de cada OFG por localidad, altura en la zona intermareal y estación del año (SU: verano, AU: otoño, WI: invierno, SP: primavera). (B) Resultados del análisis de componentes principales (primeros dos componentes principales, ver Tabla 3) aplicado sobre la representación relativa de las OFG resaltando la variabilidad espacial (panel de la izquierda, puntos grises y negros que representan el intermareal alto y bajo, respectivamente; círculos: Las Cruces, cuadrados: El Tabo, triángulos: Isla Negra) y la variabilidad temporal (panel de la derecha, puntos negro: verano, puntos blancos: primavera, puntos grises: otoño, puntos grises abiertos: invierno) en la estructura de los gremios alimenticios ontogenéticos. 
4). However, the actual pattern of statistical significance for among-seasons comparisons was highly contingent on the locality and height in the intertidal zone (Fig. 4). This shows the overriding importance of spatial over temporal differentiation in guild structure for the fish assembly under study. Thus, at Las Cruces, guild structure in autumn differed from that of summer and spring (significantly and highly significantly, respectively, Fig. 4) in low-intertidal pools. However, guild structure in summer differed (highly significantly) from those of the remaining seasons in highintertidal pools (Fig. 4). At El Tabo, in turn, summer differentiation in guild structure seems to be less evident for pools located at higher altitudes in the intertidal zone. Accordingly, differences among summer guild structure and that for the remaining three seasons were just marginally significant (after Bonferroni-adjusted significance levels) in high intertidal pools, all of the remaining cases representing significant or highly significant

\section{TABLE 3}

Loadings for each trophic guild in the first two principal components describing most variability in ontogenetic feeding guild (OFG) structure for the intertidal fish assemblages. OFGs whose representation account for most variability in each principal component (i.e. those with loadings higher than 0.10 in absolute values) are shown with an asterisk.

Valores para cada gremio trófico de los dos primeros componentes principales que describen la mayor variabilidad en la estructura de los gremios alimenticios ontogenéticos (OFG) de los ensambles de peces intermareales. Las OFG's cuyas representaciones dan cuenta de la mayor variabilidad en cada componente principal (valores mayores a 0.10 en valor absoluto) se muestran con un asterisco.

\begin{tabular}{lll}
\hline OFG & PC1 & PC2 \\
\hline A & -0.04 & $0.10^{\star}$ \\
B & 0.00 & $0.33^{\star}$ \\
C & 0.01 & $0.51^{\star}$ \\
D & -0.04 & $0.12^{\star}$ \\
O & $0.75^{\star}$ & $-0.51^{\star}$ \\
V & $-0.66^{\star}$ & $-0.59^{\star}$ \\
R & -0.01 & 0.04 \\
\hline
\end{tabular}

temporal differences in guild structure (Fig. 4). Furthermore, at this locality, guild structure in spring differed highly significantly from that in winter and autumn, irrespective of height in the intertidal zone (Fig. 4). Finally, at Isla Negra there were significant or highly significant differences in guild structure among most seasons (except for summer and winter in highintertidal pools, Fig. 4), though significance levels were somewhat lower for pools at higher intertidal levels. Thus, though the increase of the representation of carnivore guilds in spring and summer seems to have affected all fish assemblages to some extent, its actual influence varies spatially.

\section{Density compensation and functional redundancy}

In all cases, the first axis of the corresponding PCA explained most of the observed variability (> $80 \%$ ) in OFG's composition (Table 2). Further, no evidence for density compensation between species/size classes was detected along this axis (i.e., all species accounting for most variability in the first axis had similarly signed, either positive or negative, PCA loadings), with only one or two dominating overall variation (Table 2). Other main axes explained just $5 \%$ to $13 \%$ of the observed variability for OFG $\mathrm{B}, \mathrm{D}$ and $\mathrm{O}$ (Table 2), suggesting that different species/size classes explain variations through each environmental gradient (i.e., locality, height and season). Then, while the abundance of $H$. cunninghami and $H$. chilensis in OFG B explained differences between high and low tide-pools, the relative representation of the latter and $B$. chilensis did it among localities in the low intertidal (Fig. 2). A similar pattern was observed for OFG D (Fig. 2), with the abundance of $A$. microcirrhis dominating variability between heights in the intertidal, and three other species explaining differentiation in OFG composition among localities (Fig. 2). Finally, while the abundance of $D$. laevifrons explained local differentiation in the representation of OFG $\mathrm{O}$ at high tidepools, that of $H$. sordidus accounted mainly for seasonal variability at low ones due to a sudden increase in summer (Fig. 2). In this context, only PCA axes 2 and 3 for OFG B show some degree of density compensation between subsets of species/size classes (i.e., different signs in their loadings; Table 2), with 
little implication for whole OFG. Accordingly, the first PCA axis for all OFG's explained almost all variability in their total abundance (results for linear regression analysis of total abundance OFG's on corresponding PCA scores; OFG A: $\mathrm{R}^{2}=0.997$, OFG B: $\mathrm{R}^{2}=0.979$, OFG C: $\mathrm{R}^{2}=0.959$, OFG D: $\mathrm{R}^{2}=0.883$, and OFG O: $\mathrm{R}^{2}=0.938$; d.f. $=22$ and $\mathrm{P}<0.0001$ in all cases), suggesting an overall lack of functional redundancy in the intertidal fish assemblage under study.

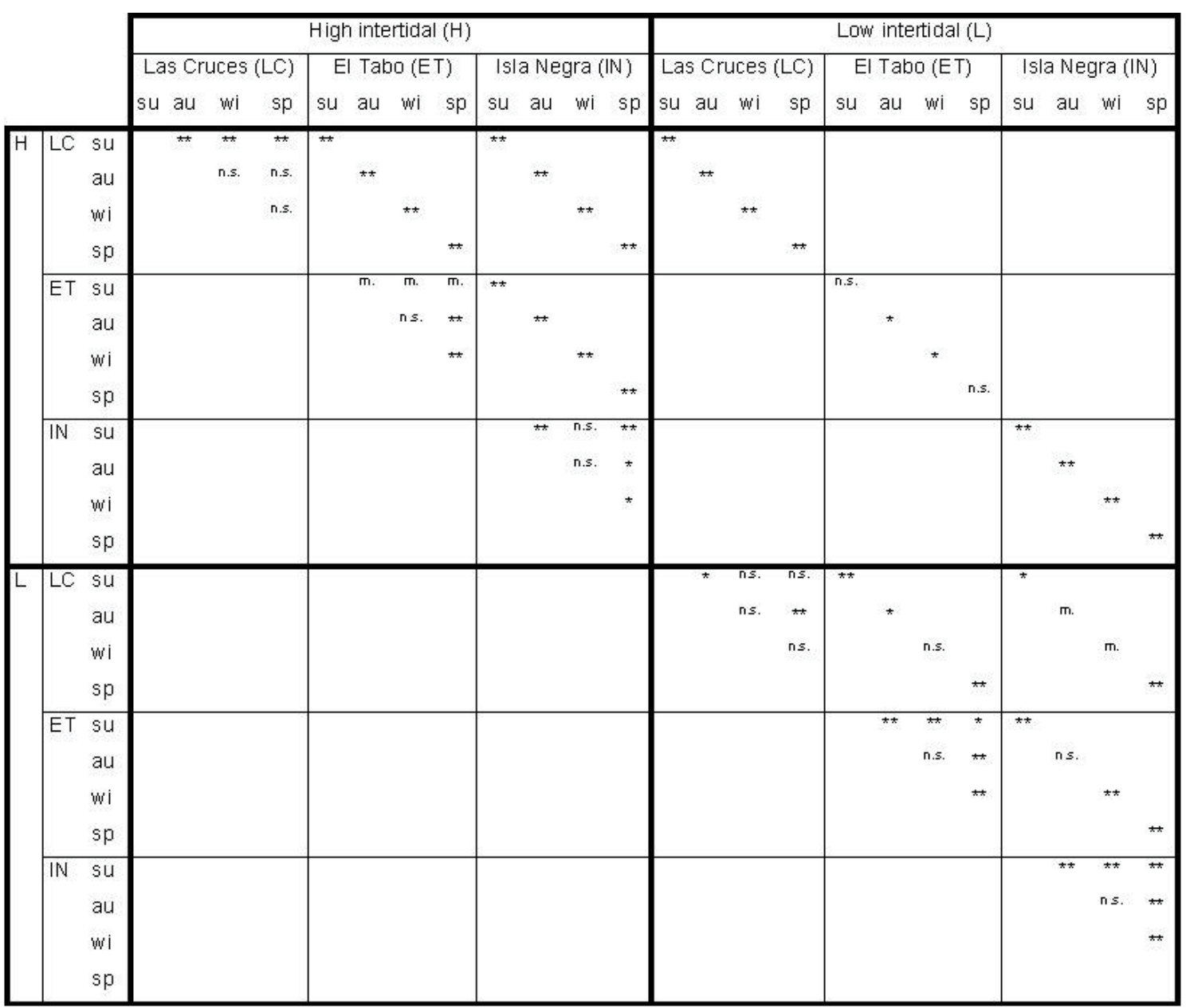

Fig. 4: Summary of the results of randomization tests for observed values of Bray-Curtis indices of similarity in guild composition $\left(\mathrm{BC}_{\mathrm{ob}}\right)$ of fish assemblages. The corresponding Bonferroni's adjusted significance level is shown for each comparison, where paired differences among levels of a given factor (i.e., height, season or localities) are tested while controlling for the remaining two: ${ }^{\text {n.s. }}$ non-significant, ${ }^{\mathrm{m}}$. marginally significant, * significant, and ** highly significant; su: summer, au: autumn, wi: winter, sp: spring. Details about the statistics of randomization tests, the associated exact probabilities and Bonferroni's adjusted significance levels are shown in Appendix (Tables A1, A2 and A3).

Resumen de los resultados de las pruebas de aleatorización para los valores de los índices Bray-Curtis de similitud en la composición de gremios de los ensambles de peces. Para cada comparación se muestran los niveles de significancia ajustados según Bonferroni, donde las diferencias pareadas entre niveles de un factor dado (i.e., altura, estación o localidad) son puestos a prueba a la vez que se controla por los dos factores restantes: ${ }^{\text {n.s. }}$ no significativo, ${ }^{\mathrm{m}}$. marginalmente significativo, * significativo, $\mathrm{y}^{* *}$ altamente significativo; su: verano, au: otoño, wi: invierno, sp: primavera. En el Apéndice se entregan detalles acerca de los estadísticos de las pruebas de aleatorización, las probabilidades exactas asociadas y los niveles de significancia ajustados según Bonferroni (Tablas A1, A2 y A3). 


\section{DISCUSSION}

The present study assessed for the first time the spatial and temporal variability in the ontogenetic feeding guild (OFG) structure (c.f. Muñoz \& Ojeda 1997, 1998, 2000) of the fish assemblage inhabiting the temperate rocky intertidal zone of central Chile. The main finding was the prevalence of spatial over temporal differentiation in the variability of OFG structure, mainly due to higher representation of omnivores at high intertidal pools in two out of three sampled localities. However, recruitment of carnivores in springsummer, and selection for lower pools by their biggest size classes, also contributed to temporal and spatial differentiation in OFG structure. In most cases, changes in the relative abundance of each ontogenetic feeding guild followed those of few dominant species with little or no compensation by other guild members, suggesting low levels of functional redundancy.

\section{Variability in OFG structure in space and time}

Overall, fish abundance was dominated by herbivore species at low-intertidal pools, followed by carnivores, and lastly by omnivores (Fig. 3A). In turn, the latter dominated high pools in two out of three surveyed localities, accounting for the observed spatial differentiation in guild structure at both large (among-localities) and small (betweenheights) scales (Fig. 3A). Physical conditions, particularly temperature, may have played a role as biotic filters (Lavorel \& Garnier 2002, Naeem \& Wright 2003, Mason et al. 2008, Farías \& Jaksic 2009, 2011), fostering functional differentiation as they vary across the vertical axis of the intertidal zone in association with the period of time the pools remain isolated from the subtidal zone (Menge \& Branch 2001, Gibson 1982). In this context, the ontogenetically consistent thermal tolerance and opportunistic habits of the two omnivore species ( $G$. laevifrons and $H$. sordidus) allow them to afford the marked variability in physical conditions and resource availability typical of high-intertidal pools throughout individuals' lifespan (Pulgar et al. 2005). In turn, at the single contrasting locality (El Tabo), a shallower slope for the rocky intertidal may have resulted in increased exposition of highpools to tides (Pulgar \& Ojeda $2000^{1}$, F. P. Ojeda, field observations), reducing vertical differentiation in physical conditions and OFG structure.

On the other hand, agreeing with the importance of tidal pools for fish recruitment (Gillanders et al. 2003), a high number of juvenile (i.e. small-sized) individuals were recorded, which do not distributed evenly through heights in the intertidal. In this context, the same environmental gradients mentioned above seem to have affected OFG structure by sorting the size classes of species that show ontogenetic differences in both thermal tolerance and diet across vertical gradients (Muñoz \& Ojeda 1998, 2000). For example, the transient species G. nigra goes through a wide range of size during its residence in the intertidal zone, small-sized individuals showing a higher distribution due to greater thermal tolerance (Pulgar \& Ojeda $2000^{1}$, Hernández et al. 2002, Pulgar et al. 2005). These individuals transit among different carnivore guilds as they grow, feeding first on amphipods, then on decapods, and ultimately on fish. Thus, since $G$. nigra is the dominant cancrivore-piscivore in the assemblage, its ontogenetic vertical migration accounted for better representation of OFG's C and D in the low intertidal zone. Furthermore, OFG's $\mathrm{C}$ and $\mathrm{D}$ were best represented in Las Cruces (Fig. $3 \mathrm{~A}$ ), where deeper low-pools allow the presence of the biggest size classes of carnivorous fishes, while the protected status of the area reduced fishing pressure on them (particularly for the heavily fished G. nigra, Godoy et al. 2010). In both cases, biotic filters acting on size (i.e. ontogenetic stage) enhanced the spatial differentiation of the functional structure of this fish assemblage.

Finally, phenological trends of carnivore specialists accounted for the observed temporal variability in OFG structure due

1 PULGAR J \& FP OJEDA (2000) Patrones en la distribución y abundancia de peces intermareales en Chile central. IX Reunión Anual de la Sociedad de Ecología de Chile, Concepción, Chile. Biological Research: R. 87. 
to their consistent higher representation during spring-summer, across localities and heights in the intertidal (Fig. 3B, right panel, Fig. 4, see details in Appendix). Among the main factors explaining seasonal variation of intertidal fish abundance in temperate zones, water temperature and specific microhabitat availability can be mentioned (Davis, 2000). In the central Chilean intertidal zone, the annual water temperature of the low pools shifts between $11.1{ }^{\circ} \mathrm{C}$ and $25.0^{\circ} \mathrm{C}\left(16.0 \pm 2.7{ }^{\circ} \mathrm{C}\right.$, mean $\pm \mathrm{SD}$ ) during low tide (data contributed by J.M. Pulgar in Hernández et al. 2002). In this case, the observed variability in the relative abundance of carnivore OFG's could be at least partially attributed to the arrival of new recruits of subtidal species that make use of intertidal pools as nursery sites (Varas and Ojeda, 1990, Hernández et al. 2002). Such highly seasonal event (Grossman 1982, Beckley 1985) occurs for most temperate water fish species during summer, when waters are warmer, and marks a strong increase in species abundance. This argument is supported by the presence of a greater abundance of small fishes (recruits) during summer months (F. P. Ojeda, personal observations).

\section{Low functional redundancy}

A pattern consistently observed across heights, localities and seasons, was a single (sometimes two) species contributing more than $50 \%$ of total OFG abundance (Fig. 2). Such uneven pattern within guilds or functional groups is common in nature (Hillebrand et al. 2008), and can arise from either (1) uneven abundance distribution of species in the regional pool and high dispersal rates among localities, (2) competitive dominant species within each guild locally precluding subordinate species from attaining high abundances, or (3) differential response of species to environmental variability with just few of them showing their environmental optima in the combination of conditions found at a given place and time. Only the last two mechanisms are expected to result in the local density compensation necessary for strict functional redundancy to occur (Rosenfeld 2002, Loreau 2004).

In the studied assemblage, the relatively low levels of temporal dissimilarity in OFG structure at low-intertidal pools resulted from the presence of numerically dominant resident species, among which members of the Blenniidae, Tripterygiidae and Labrisomidae families showed consistent high abundances (Tables 1 and 2). Also, the temporal species $G$. laevifrons y G. nigra, which stay in the intertidal zone during their juvenile stage, were among the most abundant species in high-intertidal pools (Table 1, Fig. 2). All these species consistently constituted the bulk of the guilds they joined and are also those dominating the regional species pool (Pulgar \& Ojeda 2000). Furthermore, individuals' transfer from adjacent intertidal pools (horizontal transfer) or from the subtidal zone (vertical transfer) in the case of the temporary resident species (Grossman 1982, Beckley 1985) is common for highly mobile benthic fish inhabiting intertidal zones (Gillanders et al. 2003). For these species larvae-juvenile recruitment and strong coastal marine currents would allow a wide area to harbor a similarly structured fish assemblage (Grossman 1982). Then, local OFG structure of intertidal fish assemblages should be expected to reflect to some extent the fate of the regional pool of species, with little or no functional redundancy.

Accordingly, though several members of an OFG often co-occurred, there was no evidence of density compensation among them. Whenever the abundance of dominant species varied temporally or spatially also did it that of the OFG's they joined, rendering the observed differentiation in OFG structure (Figs. 2 and 3A). For example, among-localities variability in differentiation between heights in the intertidal followed the abundance $G$. laevifrons, the dominant omnivore species in high-intertidal pools (Figs. 2 and 3A). Under these circumstances, disturbances affecting numerically dominant species may impact entire OFG's, impairing tidal-pool ecosystems functioning (Rosenfeld, 2002, Loreau, 2004). Furthermore, due to ontogenetic OFG-shifts by most species (Muñoz \& Ojeda 1998, 2000), size-biased perturbations may have stronger effects on ecosystem function than expected only from changes in taxonomic composition. In this way, fishing could have partially accounted for observed differences in the abundance of the carnivore OFG's C and D, dominated by the biggest size-classes of the heavily fished G. nigra (Godoy et al. 2010), between the 
protected area of Las Cruces and the remaining two localities. If this is true, fishing activities may be impairing ecosystem functioning through the loss or impoverishment of an entire functional group.

\section{Concluding remarks}

Although species playing similar roles in relation to a given ecosystem process or interaction of interest (e.g., depredation on similar set of prey categories) can be assessed by guild grouping, this does not account for differences in their response to environmental gradients and disturbances (Schulze \& Mooney 1993). Such differences can result in density compensation and ecological redundancy, increasing ecosystem resilience (Walker 1992, 1995, Naeem 1998, Fonseca \& Ganade 2001, Petchey \& Gaston 2002, Rosenfeld 2002, Jaksic 2003, Loreau 2004). Otherwise, species loss would directly translate into changes in the structure and functioning of the entire community (Rosenfeld 2002, Jaksic 2003, Loreau 2004). Knowing and understanding the functional organization of species assemblages require focusing on all relevant sources of variation in guild structure, at both spatial and temporal scales. Then, the relevance of ontogeny becomes evident, by linking the fate of different guilds through time and space as growing individuals shift their use of available resources. Further efforts in quantifying the interaction between OFG structure and environmental variability will foster our understanding of factors affecting ecosystem resilience, and are strongly encouraged. In this vein, the extension of the present study to other taxa and ecosystems, along with tests of the discussed mechanisms by means of manipulative experiments, are obvious steps forwards.

ACKNOWLEDGEMENTS: We dedicate this paper to the memory of Dr. Alejandro A. Muñoz (1971-2006), a talented young ecologist who left us at the plenitude of his career. We thank J.M. Rojas, F. Ogalde, V. Lobos y P. Quijada for laboratory and field assistance, and N. Godoy and two anonymous reviewers for useful comments that improved this manuscript. This study was funded by FONDAPFONDECYT grant 15010001 to FPO, to the Center for Advanced Studies in Ecology and Biodiversity (CASEB).

\section{LITERATURE CITED}

AMUNDSEN PA, T BØHN, OA POPOVA, FJ STALDVIK, YS RESHETNIKOV, NA KASHULIN \& AA LUKIN (2003) Ontogenetic niche shifts and resource partitioning in a subarctic piscivore fish guild. Hydrobiologia 497: 109-119.

ANGEL A \& FP OJEDA (2001) Structure and trophic organization of subtidal fish assemblage on the northern Chilean coast: The effects of habitat complexity. Marine Ecology Progress Series 217: 81-91.

BECKLEY LE (1985) Tide-pools fishes: Recolonization after experimental elimination. Journal of Experimental Marine Biology and Ecology 85: 287-295.

BLONDEL J (2003) Guilds or functional groups: Does it matter? Oikos 100: 223-231.

BOYLE KS \& MH HORN (2006) Comparison of feeding guild structure and ecomorphology of intertidal fish assemblages from central California and central Chile. Marine Ecology Progress Series 319: 65-84.

CASTELLANOS-GALINDO GA \& A GIRALDO (2008) Food resource use in a tropical eastern Pacific tidepool fish assemblage. Marine Biology 153: 1023-1035.

DAVIS JLD (2000) Spatial and seasonal patterns of habitat partitioning in a guild of Southern California tidepool fish. Marine Ecology Progress Series 196: 253-268.

FARÍAS AA \& FM JAKSIC (2007a) El Niño events, the lean/fat scenario, and long-term guild dynamics of vertebrate predators in a South American semiarid ecosystem. Austral Ecology 32: 225-238.

FARIAS AA \& FM JAKSIC (2007b) Effects of functional constraints and opportunism on the functional structure of a vertebrate predator assemblage. Journal of Animal Ecology 76: 246-257.

FARÍAS AA \& FM JAKSIC (2009) Hierarchical determinants of the functional richness, evenness and divergence of a vertebrate predator assemblage. Oikos 118: 591-603.

FARÍAS AA \& FM JAKSIC (2011) Low functional richness and redundancy of a predator assemblage in native forest fragments of Chiloe Island, Chile. Journal of Animal Ecology 80: 809-817.

FEINSINGER P, LA SWARM \& JA WOLFE (1985) Nectar-feeding birds on Trinidad and Tobago: Comparison of diverse and depauperate guilds. Ecological Monographs 55: 1-28.

FONSECA CR \& G GANADE (2001) Species functional redundancy, random extinctions and the stability of ecosystems. Journal of Ecology 89: 118-125.

GIBSON RN (1982) Recent studies on the biology of intertidal fishes. Oceanography and Marine Biology Annual Review 20: 363-414.

GILLANDERS BM, KW ABLE, JA BROWN, DB EGGLESTON \& PF SHERIDAN (2003) Evidence of connectivity between juvenile and adult habitats for mobile marine fauna: An important component of nurseries. Marine Ecology Progress Series 247: 281-295.

GODOY N, S GELCICH S, J VÁSQUEZ \& JC CASTILLA (2010) Spearfishing to depletion: Evidence from temperate reef fishes in Chile. Ecological Applications 20: 1504-1511.

GOTELLI NJ \& AM ELLISON (2004) A primer of ecological statistics. Sinauer Associates Inc. Massachusetts, USA.

GOTELLI NJ \& GR GRAVES (1996) Null models in ecology. Smithsonian Institution Press. 
Washington DC, USA.

GROSSMAN GD (1982) Dynamics and organization of a rocky intetidal fish assemblage: The persistence and resilience of taxocene structure. American Naturalist 119: 611-637.

HAJISAMAE S, LM CHOU \& S IBRAHIM (2004) Feeding habits and trophic relationships of fishes utilizing an impacted coastal habitat, Singapore. Hydrobiologia 520: 61-71.

HERNÁNDEZ CE, PE NEILL, JM PULGAR, FP OJEDA \& F BOZINOVIC (2002) Water temperature fluctuations and territoriality in the intertidal zone: Two possible explanations for the elevational distribution of body size in Graus nigra. Journal of Fish Biology 61: 472-488.

HILLEBRAND H, DM BENNET \& MW CADOTTE (2008) Consequences of dominance: A review of evenness effects on local and regional ecosystem processes. Ecology 89: 1510-1520.

HORN MH \& RN GIBSON (1988) Intertidal fishes. Scientific American 251: 64-70.

HORN MH (1989) Convergent evolution and community convergence: Research potential using intertidal fishes. In: Horn MH, KLM Martin \& MA Chotkowski (eds) Intertidal fishes: Life in two worlds: 356-372. Academic Press, San Diego, USA.

JACKSON AC, SD RUNDLE, MJ ATTRILL \& PA COTTON (2004) Ontogenetic changes in metabolism may determine diet shifts for a sitand-wait predator. Journal of Animal Ecology 73: 536-545.

JAKSIC FM (1981) Abuse and misuse of the term "guild" in ecological studies. Oikos 37: 397-400.

JAKSIC FM (2003) How much functional redundancy is out there, or, are we willing to do away with potential backup species? In: Bradshaw G \& P Marquet (eds) How landscapes change: Human disturbance and ecosystem disruptions in the Americas: 255-262. Ecological Studies, Volume 162 , Springer-Verlag, Berlin.

JAKSIC FM, P FEINSINGER \& JE JIMÉNEZ (1993) A long-term study on the dynamics of guild structure among predatory vertebrates at a semiarid Neotropical site. Oikos 67: 87-96.

KELLNREITNER F, M POCKBERGER \& H ASMUS (in press) Seasonal variation of assemblage and feeding guild structure of fish species in a boreal tidal basin. Estuarine, Coastal and Shelf Science.

LAVOREL S \& E GARNIER (2002) Predicting changes in community composition and ecosystem functioning from plant traits: Revisiting the Holy Grail. Functional Ecology 16: 545-556.

LOREAU M (2004) Does functional redundancy exist? Oikos 104: 606-611.

MANLY BFJ (1998) Randomization, bootstrap and Monte Carlo methods in biology. Second edition. Chapman and Hall, UK.

MASON NWH, P IRZ, C LANOISELÉE, D MOUILLOT \& C ARGILLIER (2008) Evidence that niche specialization explains species-energy relationships in lake fish communities. Journal of Animal Ecology 77: 285-296.

MENGE BA \& GM BRANCH (2001) Rocky intertidal communities. In: Bertness MD, SD Gaines \& ME Hay (eds) Marine community ecology: 221-251. Sinauer Associates, Inc., Sunderland, USA.

MUÑOZ AA \& FP OJEDA (1997) Feeding guild structure of a rocky intertidal fish assemblage in central Chile. Environmental Biology of Fishes 49: 471-479.

MUÑOZ AA \& FP OJEDA (1998) Guild structure of carnivorous intertidal fishes of the Chilean coast: Implications of ontogenetic dietary shifts. Oecologia 114: 563-573.

MUÑOZ AA \& FP OJEDA (2000) Ontogenetic changes in the diet of the herbivorous Scartichthys viridis in a rocky intertidal zone in central Chile. Journal of Fish Biology 56: 986-998.

NAEEM S (1998) Species redundancy and ecosystem reliability. Conservation Biology 12: 39-45.

NAEEM S \& JP WRIGHT (2003) Disentangling biodiversity effects on ecosystem functioning: Deriving solutions to a seemingly insurmountable problem. Ecology Letters 6: 567-579.

NUDDS TD (1983) Niche dynamics and organization of waterfowl guilds in variable environments. Ecology 64: 319-30.

PATEFIELD WM (1981) Algorithm AS159. An efficient method of generating $\mathrm{r} \times \mathrm{c}$ tables with given row and column totals. Applied Statistics 30: 91-97.

PETCHEY OL \& KJ GASTON (2002) Extinction and the loss of functional diversity. Proceedings of the Royal Society of London B 269: 1721-1727.

PETCHEY OL \& KJ GASTON (2006) Functional diversity: Back to basics and looking forward. Ecology Letters 9: 741-758.

PIANKA ER (1980) Guild structure in desert lizards. Oikos 35: 194-201.

POLIS GA (1984) Age structure component of niche width and intra-specific resource partitioning: Can age groups function as ecological species? The American Naturalist 123: 541-564.

PULGAR J, F BOZINOVIC \& FP OJEDA (2005) Local distribution and thermal ecology of two intertidal fishes. Oecologia 142: 511-520.

PULGAR J, M ÁLVAREZ, J MORALES, M GARCÍAHUIDOBRO, M ALDANA, FP OJEDA \& VM PULGAR (2011) Impact of oceanic upwelling on morphometric and molecular indices of an intertidal fish Scartichthys viridis (Blenniidae). Marine and Freshwater Behaviour and Physiology 44: 33-42.

R DEVELOPMENT CORE TEAM (2006) R: A language and environment for statistical computing. URL: http://www.R-project.org. R Foundation for Statistical Computing, Vienna, Austria.

REUM JCP \& TE ESSINGTON (2008) Seasonal variation in guild structure of the Puget sound demersal fish community. Estuaries and Coasts 31: 790-801.

ROJAS JM \& FP OJEDA (2010) Spatial distribution of intertidal fishes: A pattern dependent on body size and predation risk? Environ Biology of Fishes 87: 175-185.

ROOT R (1967) The niche exploitation pattern of the Blue-gray gnatcatcher. Ecological Monographs 37 : 317-350.

ROSENFELD JS (2002) Functional redundancy in ecology and conservation. Oikos 98: 156-162.

SCHULZE ED \& HA MOONEY (1993) Ecosystem function of diversity: A summary. In: Schulze ED \& HA Mooney (eds) Biodiversity and ecosystem function: 497-510. Ecological Studies Analysis and Synthesis. Springer-Verlag, Germany.

SIMBERLOFF D \& T DAYAN (1991) The guild concept and the structure of ecological communities. Annual Review of Ecology and Systematics 22: 115-143.

SPECZIÁR A \& ET REZSU (2009) Feeding guilds and food resource partitioning in a lake fish assemblage: An ontogenetic approach. Journal of 
Fish Biology 75: 247-267.

STEPIEN CA (1990) Population structure, diets and biogeographic relationships of a rocky intertidal fish assemblage in central Chile: High levels of herbivory in a temperate system. Bulletin of Marine Science 47: 598-612.

VARAS E \& FP OJEDA (1990) Intertidal fish assemblages of the central Chilean coast: Diversity, abundance and trophic patterns. Revista de Biología Marina, Valparaíso (Chile) 25: 59-70.

WALKER B (1992) Biodiversity and ecological redundancy. Conservation Biology 6: 18-23.

WALKER B (1995) Conserving biological diversity through ecosystem resilience. Conservation Biology 9: 747-752.
WENNHAGEN H \& L PIHL (2002) Fish feeding guilds in shallow rocky and soft bottom areas on the Swedish west coast. Journal of Fish Biology 61: 207-228.

WERNER EE \& JF GILLIAM (1984) The ontogenetic niche and species interactions in size-structured populations. Annual Review of Ecology and Systematics 15: 393-425.

WERNER EE \& DJ HALL (1988) Ontogenetic habitat shifts in bluegill: The foraging rate-predation risk trade-off. Ecology 69: 1352-1366.

WILSON J (1999) Guilds, functional types and ecological groups. Oikos 86: 507-522.

Associate Editor: Matías Arim

Received February 16, 2011; accepted November 23, 2011

\section{APPENDIX}

Detailed results of randomization tests.

Resultados detallados de las pruebas de aleatorización.

TABLE A1

Results of randomization tests for observed values of Bray-Curtis indices of similarity in guild composition $\left(\mathrm{BC}_{\mathrm{ob}}\right)$ between fish assemblages at high and low pools in the intertidal, by season and locality. Expected values $\left(\mathrm{BC}_{\mathrm{ex}}\right)$, representing the mean values of Bray-Curtis indices obtained from 5000 randomizations of species abundances, along with the associated probability and significance for $\mathrm{BC}_{\mathrm{ob}}$ (n.s. non-significant, * significant: $\mathrm{P}<0.05$, and ** highly significant: $\mathrm{P}<0.01$ ) are shown.

Resultados de las pruebas de randomización para los valores observados de los índices de similitud de Bray-Curtis en la composición gremial $\left(\mathrm{BC}_{\mathrm{ob}}\right)$ entre ensambles de peces de pozas altas y bajas del intermareal, y por estación y localidad. Se muestran los valores esperados $\left(\mathrm{BC}_{\mathrm{ex}}\right)$ que representan los valores promedios de los índices de BrayCurtis obtenidos de 5000 randomizaciones de las abundacias de las especies junto con la probabilidad asociada y significancia de $\operatorname{los} \mathrm{BC}_{\mathrm{ob}}$ (n.s. no significativo, * significativo: $\mathrm{P}<0.05, \mathrm{y}$ ** muy significativo: $\mathrm{P}<0.01$ ).

\begin{tabular}{lccccc}
\hline Season & Locality & $\mathrm{BC}_{\mathrm{ob}}$ & $\mathrm{BC}_{\mathrm{ex}}( \pm \mathrm{SD})$ & $\mathrm{P}\left(\leq \mathrm{BC}_{\mathrm{ob}}\right)$ & \\
\hline summer & Las Cruces & 0.26 & $0.82( \pm 0.06)$ & $<0.0002$ & $* *$ \\
& El Tabo & 0.90 & $0.92( \pm 0.03)$ & 0.1716 & n.s. \\
& Isla Negra & 0.77 & $0.93( \pm 0.03)$ & $<0.0002$ & $* *$ \\
autumn & Las Cruces & 0.09 & $0.91( \pm 0.04)$ & $<0.0002$ & $* *$ \\
& El Tabo & 0.79 & $0.88( \pm 0.04)$ & 0.0410 & $*$ \\
\multirow{4}{*}{ winter } & Isla Negra & 0.47 & $0.90( \pm 0.04)$ & $<0.0002$ & $* *$ \\
& Las Cruces & 0.02 & $0.87( \pm 0.05)$ & $<0.0002$ & $* *$ \\
& El Tabo & 0.76 & $0.86( \pm 0.05)$ & 0.0410 & $*$ \\
spring & Isla Negra & 0.60 & $0.91( \pm 0.04)$ & $<0.0002$ & $* *$ \\
& Las Cruces & 0.03 & $0.90( \pm 0.04)$ & $<0.0002$ & $* *$ \\
& El Tabo & 0.75 & $0.81( \pm 0.06)$ & 0.1550 & n.s. \\
& Isla Negra & 0.33 & $0.82( \pm 0.06)$ & $<0.0002$ & $* *$ \\
\hline
\end{tabular}


TABLE A2

Results of randomization tests for observed values of Bray-Curtis indices of similarity $\left(\mathrm{BC}_{\mathrm{ob}}\right)$ in guild composition of fish assemblages among localities, by height in the intertidal and season. $\mathrm{BC}_{\mathrm{ex}}, \mathrm{BC}_{\mathrm{ob}}$ and $\mathrm{P}\left(\leq \mathrm{BC}_{\mathrm{ob}}\right)$ as in Table 1 (Bonferroni adjusted significance levels: $\mathrm{a} / 3$, n.s. nonsignificant, ${ }^{\mathrm{m}}$. marginally significant: $\mathrm{P}<0.0333$, * significant: $\mathrm{P}<0.0167$, and ${ }^{* *}$ highly significant: $\mathrm{P}<0.0033$ ).

Resultados de las pruebas de randomización para los valores observados de los índices de silimitud de Bray-Curtis $\left(\mathrm{BC}_{\mathrm{ob}}\right)$ en la composición gremial de los ensambles de peces entre localidades, y por altura en el intermareal y por estación. $\mathrm{BC}_{\mathrm{ex}}, \mathrm{BC}_{\mathrm{ob}}$ y $\mathrm{P}\left(\leq \mathrm{BC}_{\mathrm{ob}}\right)$ como en la Tabla 1 (niveles de significancia de Bonferroni ajustados: a/3, n.s. no significativo, ${ }^{m}$ marginalmente significativo: $\mathrm{P}<0.0333$, * significativo: $\mathrm{P}<0.0167$, and ** muy significativo: $\mathrm{P}<$ $0.0033)$.

\begin{tabular}{|c|c|c|c|c|c|c|}
\hline Height & Season & Comparison & $\mathrm{BC}_{\mathrm{ob}}$ & $\mathrm{BC}_{\mathrm{ex}}( \pm \mathrm{SD})$ & $\mathrm{P}\left(\leq \mathrm{BC}_{\mathrm{ob}}\right)$ & \\
\hline \multirow[t]{12}{*}{ Low } & summer & Las Cruces-El Tabo & 0.77 & $0.92( \pm 0.03)$ & $<0.0002$ & ** \\
\hline & & Las Cruces-Isla Negra & 0.84 & $0.92( \pm 0.03)$ & 0.0092 & * \\
\hline & & El Tabo-Isla Negra & 0.84 & $0.96( \pm 0.01)$ & $<0.0002$ & ** \\
\hline & autumn & Las Cruces-El Tabo & 0.86 & $0.93( \pm 0.02)$ & 0.0078 & * \\
\hline & & Las Cruces-Isla Negra & 0.85 & $0.92( \pm 0.03)$ & 0.0214 & $\mathrm{~m}$. \\
\hline & & El Tabo-Isla Negra & 0.89 & $0.93( \pm 0.03)$ & 0.0884 & n.s. \\
\hline & winter & Las Cruces-El Tabo & 0.85 & $0.89( \pm 0.04)$ & 0.1408 & n.s. \\
\hline & & Las Cruces-Isla Negra & 0.79 & $0.89( \pm 0.04)$ & 0.0210 & $\mathrm{~m}$. \\
\hline & & El Tabo-Isla Negra & 0.87 & $0.95( \pm 0.02)$ & $<0.0002$ & ** \\
\hline & spring & Las Cruces-El Tabo & 0.74 & $0.90( \pm 0.03)$ & 0.0002 & ** \\
\hline & & Las Cruces-Isla Negra & 0.76 & $0.89( \pm 0.04)$ & 0.0022 & ** \\
\hline & & El Tabo-Isla Negra & 0.75 & $0.91( \pm 0.03)$ & 0.0002 & ** \\
\hline \multirow[t]{12}{*}{ High } & summer & Las Cruces-El Tabo & 0.13 & $0.83( \pm 0.06)$ & $<0.0002$ & ** \\
\hline & & Las Cruces-Isla Negra & 0.49 & $0.84( \pm 0.06)$ & $<0.0002$ & ** \\
\hline & & El Tabo-Isla Negra & 0.55 & $0.89( \pm 0.04)$ & $<0.0002$ & ** \\
\hline & autumn & Las Cruces-El Tabo & 0.01 & $0.88( \pm 0.06)$ & $<0.0002$ & ** \\
\hline & & Las Cruces-Isla Negra & 0.54 & $0.93( \pm 0.04)$ & $<0.0002$ & ** \\
\hline & & El Tabo-Isla Negra & 0.39 & $0.88( \pm 0.06)$ & $<0.0002$ & ** \\
\hline & winter & Las Cruces-El Tabo & 0.00 & $0.88( \pm 0.07)$ & $<0.0002$ & ** \\
\hline & & Las Cruces-Isla Negra & 0.42 & $0.92( \pm 0.05)$ & $<0.0002$ & ** \\
\hline & & El Tabo-Isla Negra & 0.41 & $0.88( \pm 0.07)$ & $<0.0002$ & ** \\
\hline & spring & Las Cruces-El Tabo & 0.07 & $0.89( \pm 0.05)$ & $<0.0002$ & ** \\
\hline & & Las Cruces-Isla Negra & 0.71 & $0.90( \pm 0.04)$ & 0.0006 & ** \\
\hline & & El Tabo-Isla Negra & 0.28 & $0.87( \pm 0.06)$ & $<0.0002$ & ** \\
\hline
\end{tabular}


TABLE A3

Results of randomization tests for observed values of Bray-Curtis indices of similarity $\left(\mathrm{BC}_{\mathrm{ob}}\right)$ in guild composition of fish assemblages among seasons, by height in the intertidal and locality. $\mathrm{BC}_{\mathrm{ex}}$, $\mathrm{BC}_{\mathrm{ob}}$ and $\mathrm{P}\left(\leq \mathrm{BC}_{\mathrm{ob}}\right)$ as in Table 1 (Bonferroni adjusted significance levels: $\mathrm{a} / 6$, n.s. non-significant, $\mathrm{m}$. marginally significant: $\mathrm{P}<0.0167$, * significant: $\mathrm{P}<0.0083$, and ${ }^{*}$ highly significant: $\left.\mathrm{P}<0.0017\right)$.

Resultados de las pruebas de randomización para los valores observados de los índices de silimitud de Bray-Curtis $\left(\mathrm{BC}_{\mathrm{ob}}\right)$ en la composición gremial de los ensambles de peces entre estaciones, y por altura en el intermareal y por localidad.. $\mathrm{BC}_{\mathrm{ex}}, \mathrm{BC}_{\mathrm{ob}}$ y $\mathrm{P}\left(\leq \mathrm{BC}_{\mathrm{ob}}\right)$ como en la Tabla 1 (niveles de significancia de Bonferroni ajustados: a/6, n.s. no significativo, ${ }^{m}$. marginalmente significativo: $\mathrm{P}<0.0167$, * significativo: $\mathrm{P}<0.0083$, and ${ }^{* *}$ muy significativo: $\mathrm{P}<0.0017$ ).

\begin{tabular}{|c|c|c|c|c|c|c|}
\hline Height & Locality & Comparison & $\mathrm{BC}_{\mathrm{ob}}$ & $\mathrm{BC}_{\mathrm{ex}}( \pm \mathrm{SD})$ & $\mathrm{P}\left(\leq \mathrm{BC}_{\mathrm{ob}}\right)$ & \\
\hline \multirow[t]{18}{*}{ Low } & Las Cruces & summer-autumn & 0.77 & $0.89( \pm 0.04)$ & 0.0020 & * \\
\hline & & summer-winter & 0.82 & $0.85( \pm 0.05)$ & 0.2684 & n.s. \\
\hline & & summer-spring & 0.82 & $0.88( \pm 0.04)$ & 0.0542 & n.s. \\
\hline & & autumn-winter & 0.91 & $0.85( \pm 0.05)$ & 0.8978 & n.s. \\
\hline & & autumn-spring & 0.73 & $0.89( \pm 0.04)$ & 0.0002 & ** \\
\hline & & winter-spring & 0.80 & $0.85( \pm 0.05)$ & 0.1992 & n.s. \\
\hline & El Tabo & summer-autumn & 0.86 & $0.95( \pm 0.02)$ & $<0.0002$ & ** \\
\hline & & summer-winter & 0.87 & $0.96( \pm 0.01)$ & $<0.0002$ & ** \\
\hline & & summer-spring & 0.89 & $0.95( \pm 0.02)$ & 0.0074 & * \\
\hline & & autumn-winter & 0.93 & $0.94( \pm 0.02)$ & 0.1574 & n.s. \\
\hline & & autumn-spring & 0.81 & $0.94( \pm 0.02)$ & $<0.0002$ & ** \\
\hline & & winter-spring & 0.83 & $0.94( \pm 0.02)$ & $<0.0002$ & ** \\
\hline & Isla Negra & summer-autumn & 0.68 & $0.92( \pm 0.03)$ & $<0.0002$ & ** \\
\hline & & summer-winter & 0.77 & $0.95( \pm 0.02)$ & $<0.0002$ & ** \\
\hline & & summer-spring & 0.81 & $0.93( \pm 0.03)$ & $<0.0002$ & ** \\
\hline & & autumn-winter & 0.86 & $0.92( \pm 0.03)$ & 0.0626 & n.s. \\
\hline & & autumn-spring & 0.59 & $0.90( \pm 0.04)$ & $<0.0002$ & ** \\
\hline & & winter-spring & 0.71 & $0.92( \pm 0.03)$ & $<0.0002$ & ** \\
\hline \multirow[t]{18}{*}{ High } & Las Cruces & summer-autumn & 0.61 & $0.94( \pm 0.03)$ & $<0.0002$ & ** \\
\hline & & summer-winter & 0.58 & $0.94( \pm 0.03)$ & $<0.0002$ & ** \\
\hline & & summer-spring & 0.57 & $0.94( \pm 0.03)$ & $<0.0002$ & ** \\
\hline & & autumn-winter & 0.95 & $0.96( \pm 0.02)$ & 0.2190 & n.s. \\
\hline & & autumn-spring & 0.94 & $0.97( \pm 0.02)$ & 0.0988 & n.s. \\
\hline & & winter-spring & 0.99 & $0.96( \pm 0.02)$ & 0.9770 & n.s. \\
\hline & El Tabo & summer-autumn & 0.71 & $0.86( \pm 0.05)$ & 0.0112 & $\mathrm{~m}$. \\
\hline & & summer-winter & 0.71 & $0.86( \pm 0.05)$ & 0.0114 & $\mathrm{~m}$. \\
\hline & & summer-spring & 0.72 & $0.86( \pm 0.05)$ & 0.0152 & $\mathrm{~m}$. \\
\hline & & autumn-winter & 1.00 & $0.83( \pm 0.07)$ & 1.0000 & n.s. \\
\hline & & autumn-spring & 0.55 & $0.83( \pm 0.07)$ & 0.0010 & ** \\
\hline & & winter-spring & 0.55 & $0.83( \pm 0.07)$ & 0.0008 & ** \\
\hline & Isla Negra & summer-autumn & 0.70 & $0.90( \pm 0.04)$ & $<0.0002$ & ** \\
\hline & & summer-winter & 0.78 & $0.90( \pm 0.05)$ & 0.0188 & n.s. \\
\hline & & summer-spring & 0.49 & $0.85( \pm 0.06)$ & $<0.0002$ & ** \\
\hline & & autumn-winter & 0.90 & $0.88( \pm 0.05)$ & 0.6598 & n.s. \\
\hline & & autumn-spring & 0.64 & $0.84( \pm 0.07)$ & 0.0040 & * \\
\hline & & winter-spring & 0.62 & $0.84( \pm 0.07)$ & 0.0030 & * \\
\hline
\end{tabular}

